\title{
Independent Expression of the $A$ Gene of the Tryptophan Operon of Escherichia coli during Tryptophan Starvation
}

\author{
By W. J. BRAMMAR \\ Department of Molecular Biology, University of Edinburgh, \\ King's Buildings, Mayfield Road, Edinburgh, EH9 $3 \mathrm{JR}$
}

(Received 4 December 1972)

\begin{abstract}
SUMMARY
Two complementary frameshift mutations in the $\operatorname{trp} A$ gene of Escherichia coli have been isolated following recombination of the pseudowild double mutant with the wild-type strain. One of these mutations recombines with a third, distal frameshift mutation to give a slow-growing $\operatorname{Trp}^{+}$strain. Consideration of the relevant RNA codon sequences suggests that the slow-growing recombinant should contain a unique tryptophan codon in the altered reading phase between the frameshift mutations. This prediction has been verified by analysis of the purified tryptophan synthetase A protein from the double mutant. The preferential synthesis of A protein normally associated with prolonged tryptophan starvation is eliminated in the strain which has a tryptophan residue in its A protein.
\end{abstract}

\section{INTRODUCTION}

The biosynthetic tryptophan (trp) operon of Escherichia coli contains five structural genes, $\operatorname{trp} E, D, C, B$ and $A$, which code for the five polypeptide chains involved in the conversion of the aromatic precursor chorismic acid to tryptophan (Yanofsky \& Lennox, I959; Creighton \& Yanofsky, 1969). Expression of the operon is controlled by the protein product of an unlinked regulatory gene, $\operatorname{trp} R$ (Cohen \& Jacob, I959; Morse \& Yanofsky, 1969; Zubay, Morse, Schrenk \& Miller, I972). An operator locus has been identified by the isolation of $c i s$-acting constitutive mutants mapping at the $E$ gene end of the operon (Hiraga, I969). The five structural genes are transcribed into a single messenger RNA molecule, which is sequentially synthesized and translated from the operator-proximal $E$ gene towards the distal $A$ gene (Imamoto, Morikawa \& Sato, I965; Imamoto \& Yanofsky, 1967).

When the $\operatorname{trp}$ operon is derepressed during normal growth the enzymes are produced in equimolar quantities (Ito, Cox \& Yanofsky, 1969). This situation does not hold, however, when a tryptophan auxotroph is subjected to prolonged tryptophan starvation (Somerville \& Yanofsky, 1964). The tryptophan synthetase $\alpha$ subunit, coded by the $\operatorname{trp} A$ gene, continues to be synthesized for some $30 \mathrm{~h}$ of starvation, whereas the other products of the operon are no longer produced after a few hours. Somerville \& Yanofsky (I964) have suggested that this preferential synthesis of the $\alpha$ subunit is due to independent translation of the messenger RNA corresponding to the $\operatorname{trp} A$ gene, made possible by the absence of tryptophan from the $\alpha$ subunit (Henning, Helinski, Chao \& Yanofsky, 1962). This hypothesis could be directly tested if there were available an $\alpha$ subunit variant which contained a tryptophan codon. This paper describes the isolation of such a variant, and shows that the altered $A$ gene is no longer preferentially expressed during tryptophan starvation. 


\section{METHODS}

Bacteria and phage. The various trp mutants used in this study were crossed into the w3 I 0 strain of Escherichia KI 2 by transduction with PI $k c$, using a W3I Io $(\operatorname{ton} B, \operatorname{trp} E-A)$ deletion as recipient, and selecting for growth on plates supplemented with indole (Io $\mu \mathrm{g} / \mathrm{ml}$ ). Strains $\operatorname{trp} A_{4} 6^{a s p} P R_{3}$ and $\operatorname{trp} A_{4} 6^{a s p} P R_{3} F R_{7}$ were generously provided by $\mathrm{Dr} \mathrm{H}$. Berger: other bacterial strains and the generalized transducing phage PI $k c$ were from the collection of Dr C. Yanofsky.

Media. The minimal medium of Spizizen (1958) was used with glucose $(0.2 \%, \mathrm{w} / \mathrm{v})$ as carbon source. Where possible this was supplemented with $0.05 \%(\mathrm{w} / \mathrm{v})$ Difco Bacto acid hydrolysed casein. Amino acids were added as required at $20 \mu \mathrm{g} / \mathrm{ml}$. The rich medium was L-broth (Lennox, 1955) containing (g/l): Difco Bacto Tryptone, 10; Difco Bacto Yeast Extract, 5; $\mathrm{NaCl}, 5 ;$ glucose, I, adjusted to $\mathrm{pH} 7 \cdot 2$. Media for plates were solidified with $\mathrm{I} \cdot 5 \%(\mathrm{w} / \mathrm{v})$ agar.

Transduction. Pi $k c$ lysates were prepared by the confluent lysis technique (Swanstrom \& Adams, I95I) and were used for transduction as described by Yanofsky \& Lennox (I959).

Recombination distances between $\operatorname{trp} A$ mutants were obtained as described by Yanofsky et al. (1964). When the recipient was $c y s B$, $t r p$, the ratio of $c y s^{+} t r p^{+}$to $c y s^{+}$transductants was multiplied by 2 to correct for the $50 \%$ cysB-trp linkage (Yanofsky \& Lennox, 1959). When a hiscysBtrp recipient was used the ratio of $c y s B^{+} t r p^{+}$to $h i s^{+}$transduction was scored. When $c y s^{+}$and $t r p^{+}$are selected together, the $50 \%$ cys-trp linkage exactly compensates for the relatively inefficient transduction of the his region compared with that of the cys-trp region (Yanofsky \& Lennox, 1959). In all crosses the $c y s^{+} t r p^{+}$transductants were selected on minimal plates supplemented with $0 \cdot 1 \mu \mathrm{g} / \mathrm{ml} 5$-methyl-DL-tryptophan, which suppresses the growth of leaky mutants without affecting the growth of wild-type recombinants or the frequency of recombination (Yanofsky et al. 1964).

Penicillin enrichment for trp recombinants. The procedure was based on that described by Allen \& Yanofsky (I963). After exposure of the cysBtrp ${ }^{+}$recipient to transducing phage, organisms were harvested, washed in $0^{\circ} \mathrm{I}$ M-sodium citrate buffer, $\mathrm{pH} 7 \cdot 0$, resuspended in minimal medium containing $0.2 \%(\mathrm{w} / \mathrm{v})$ glucose and $20 \mu \mathrm{g} / \mathrm{ml} \mathrm{L}$-tryptophan, and grown overnight at $37^{\circ} \mathrm{C}$. The $c y s^{+}$transductants so selected were diluted 50-fold into fresh minimal medium containing glucose $(0.2 \%, \mathrm{w} / \mathrm{v})$ and tryptophan $(20 \mu \mathrm{g} / \mathrm{ml})$ and grown to about $2 \times 10^{8}$ organisms $/ \mathrm{ml}$. Organisms were harvested and washed twice with minimal medium, resuspended at $\mathrm{IO}^{6}$ organisms $/ \mathrm{ml}$ in minimal medium + glucose $(0.2 \%$, w/v) and grown for a further $3 \mathrm{~h}$ at $37^{\circ} \mathrm{C}$. Benzylpenicillin ( $1000 \mathrm{u} / \mathrm{ml}$ ) was then added and incubation was continued for a further $2 \mathrm{~h}$ before the organisms were washed twice in minimal medium and resuspended in the original volume of L-broth to grow to saturation. Approximately 200 organisms/plate were spread on to glucose-minimal agar plates supplemented with L-tryptophan $(20 \mu \mathrm{g} / \mathrm{ml})$. Plates were incubated at $37{ }^{\circ} \mathrm{C}$ for $48 \mathrm{~h}$ before replication to unsupplemented glucose-minimal agar plates to screen for trp colonies.

Preparation of extracts. Bacteria were harvested by centrifugation at $0^{\circ} \mathrm{C}$, washed with one-half the original volume of cold $0 \cdot 1 \mathrm{M}$-tris- $\mathrm{HCl}, \mathrm{pH} 7 \cdot 8$, and resuspended in I/50 volume of the same buffer. Organisms were disrupted with a M.S.E. sonifier, and the debris was removed by centrifugation at $38000 \mathrm{~g}$ for $15 \mathrm{~min}$.

Enzyme assays. The A and B subunits of tryptophan synthetase were assayed by indoleutilization as described by Smith \& Yanofsky (1962). A crude extract prepared from the $A$ gene nonsense mutant $\operatorname{trp} A 96$ was used as the source of the B protein. Specific activities 
are expressed as units of enzyme activity/mg of protein. Protein was determined by the procedure of Lowry, Rosebrough, Farr \& Randall (195I).

Purification of tryptophan synthetase $A$ proteins. Wild-type and mutant tryptophan synthetase A proteins were purified from 501 batches of bacteria as described by Henning et al. (1962) as far as the chromatography on G Ioo Sephadex. All buffers contained $10^{-3} \mathrm{M}-\beta$-mercaptoethanol and $10^{-3} \mathrm{M}$-EDTA. The precipitated fractions from the $\mathrm{G} 100$ Sephadex column were resuspended in the minimal volume of 0.1 M-potassium phosphate buffer, $\mathrm{pH} 7 \cdot 2$. After centrifuging at $38000 \mathrm{~g}$ for Io min to remove solids, the supernatant was applied to a $100 \times 2 \mathrm{~cm}$ diam. column of DEAE-Sephadex, equilibrated with $0.03 \mathrm{M}$ potassium phosphate buffer, $\mathrm{pH} 7 \cdot 2$. A linear gradient of $0.03 \mathrm{M}$ to $0.3 \mathrm{M}$-potassium phosphate $(700 \mathrm{ml}$ in each vessel) was applied at a flow rate of $20 \mathrm{ml} / \mathrm{h}$, and $12 \mathrm{ml}$ fractions were collected. The peak fractions from this column usually have a specific activity of 2500 to $3500 \mathrm{u} . / \mathrm{mg}$ protein. Protein from the pooled peak fractions was precipitated with $0.43 \mathrm{~g}$ $\left(\mathrm{NH}_{4}\right)_{2} \mathrm{SO}_{4} / \mathrm{ml}$. The precipitate was collected by centrifugation at $38000 \mathrm{~g}$ for $20 \mathrm{~min}$,

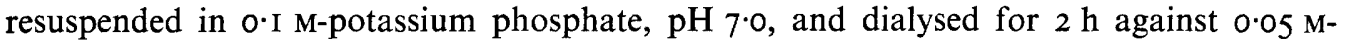
potassium phosphate, $\mathrm{pH} 7 \cdot 0$. After removal of insoluble material by centrifugation at $38000 \mathrm{~g}$ for $10 \mathrm{~min}$, the protein was rechromatographed on a Sephadex G Ioo column, $80 \times 2 \mathrm{~cm}$, at a flow rate of $20 \mathrm{ml} / \mathrm{h} ; 5 \mathrm{ml}$ fractions were collected. The peak fractions from this column usually had a specific activity of 3500 to $4500 \mu / \mathrm{mg}$ protein. Peak fractions from the Sephadex column were precipitated with $0.43 \mathrm{~g}\left(\mathrm{NH}_{4}\right)_{2} \mathrm{SO}_{4} / \mathrm{ml}$. The protein pelleted after centrifugation at $38000 \mathrm{~g}$ for $20 \mathrm{~min}$, was resuspended in $0.1 \mathrm{M}$-potassium phosphate, $\mathrm{pH} 7 \cdot 0$, and again chromatographed on a column of DEAE-Sephadex, $100 \times 2 \mathrm{~cm}$, at a flow rate of $\mathrm{I} 5 \mathrm{ml} / \mathrm{h} ; 5 \mathrm{ml}$ fractions were collected. Specific activities in the peak fractions were usually about $4800 \mathrm{u} / \mathrm{mg}$ at this stage.

\section{RESULTS}

\section{Recovery of frameshift mutants from a pseudowild revertant strain}

Escherichia coli strain $\operatorname{trp} A_{4} 6^{a s p} P R_{3} F R 7$, though phenotypically indistinguishable from wild-type, contains two frameshift mutations of opposite phase, between which are two missense mutations in adjacent bases (Berger, Brammar \& Yanofsky, 1968). The pertinent amino acid and RNA codon sequences are shown in Fig. I. An attempt was made to separate the two frameshift mutations by recombination in a genetic cross between $A 46^{a s p} P R_{3} F R_{7}$ and a $t r p^{+}$wild-type strain. A PI-lysate grown on $A 46^{a s p} P R_{3} F R_{7}$ was used to transduce a cysBtrp ${ }^{+}$recipient to $c y s^{+}$, and the resulting $c y s^{+}$transductants were screened for the presence of trp recombinants following a penicillin enrichment procedure as described in Methods.

Tryptophan auxotrophs recovered in this way fell into two phenotypic classes (Table I). Some were able to grow very slowly on minimal agar, while others failed to grow. Mutants of both classes appeared to be frameshifts, since they were stimulated to revert by ICR I9I, a powerful frameshift mutagen, but not by NTG, which is known to stimulate largely base replacements (Whitfield, Martin \& Ames, 1966). Mutants of both classes fail to grow on plates containing $2 \mu \mathrm{g} / \mathrm{ml}$ indole $+100 \mu \mathrm{g} / \mathrm{ml} \mathrm{5-methyl-DL-tryptophan} \mathrm{(Brammar,} \mathrm{Berger} \mathrm{\&}$ Yanofsky, 1967), and show no detectable A protein activity in the conversion of indole to tryptophan (Crawford \& Yanofsky, 1958). Their behaviour in both of these tests is characteristic of immunologically non-crossreacting $\left(\mathrm{CRM}^{-}\right) A$ gene mutants, and is therefore consistent with their classification as frameshift mutants.

To verify that the mutants isolated were derived by recombination from $A 46^{a s p} P R_{3} F R_{7}$, 
Strain ...Pro - Leu - Gln - Gly - Phe - Gly - Ile... Phenotype

Wild-type

A46

$A 46^{a s p}$

$A 46^{a s p} P_{3}$

$\mathrm{A}_{4} 6^{a s p} \mathrm{PR}_{3} \mathrm{FR}_{7}$

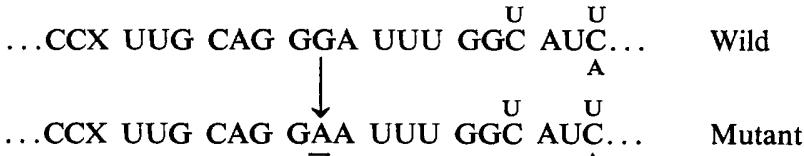<smiles>C1CCCCC1</smiles>

...CCX UUG CAG GAUU UUU GGC AUC. . $\downarrow+\mathbf{I}$

-Asp-

...CCX AUU GCA GGA UUU UGG UAU<smiles>CC(C)(C)C</smiles>

...CCX AUU GCA GGA UUU UGC AUC.. -Pro - Ile - Ala - Gly - Phe - Cys - Ile-
Mutant, but suppressible

Trp ${ }^{+}$; slow growing

Wild

Fig. I. Derivation of the multiple mutant strain $\operatorname{trp} A 46^{a s p} P R_{3} F R_{7}$. The pseudowild strain $A_{4} 6^{a s p} P R_{3} F R 7$ was derived in four successive mutational steps from the wild-type. The first step was a transition of the second $\mathrm{G}$ of the gly-210 codon to an $\mathrm{A}$, resulting in the gly $\rightarrow$ glu replacement of mutant trpA46 (Henning \& Yanofsky, 1962). Step (2) was a transversion of the third position A of the mutant glu-2 IO codon (GAA) of $\operatorname{trp} A 46$ to $\mathrm{U}$, converting residue 210 into asp ( $A 46^{a s p}$ ). Although the $A 46^{a s p}$ is itself $\mathrm{Trp}^{-}$, the glu $\rightarrow$ asp replacement could be selected in the presence of a missense suppressor which misreads asp codons (Berger \& Yanofsky, 1967). Step (3) arose as a slow-growing (partial) revertant of $A 46^{a s p}$, and was subsequently shown to be a single nucleotide addition frameshift event (Berger et al. 1968). Event (4) was a compensatory deletion of G from the gly 212 codon, restoring the wild-type reading frame and phenotype (Berger et al. 1968).

Table I. Characteristics of trpA mutants derived from $A_{4} 6^{a s p} P R_{3} F R_{7}$

\begin{tabular}{|c|c|c|c|c|c|}
\hline \multirow[b]{2}{*}{ Strain } & \multirow{2}{*}{$\begin{array}{l}\text { Relative colony } \\
\text { size on minimal } \\
\text { plates }\end{array}$} & \multirow{2}{*}{$\begin{array}{c}\text { Growth on } \\
\text { indole }+5 \mathrm{MT}^{*}\end{array}$} & \multicolumn{2}{|c|}{ Reversion response $\dagger$ to } & \multirow[b]{2}{*}{ A/B ratio $\ddagger$} \\
\hline & & & ICR & NTG & \\
\hline$A_{4} 6^{a s p} P R_{3} F R_{7}$ & 100 & + & . & . & $1 \cdot 0$ \\
\hline$A 46^{a s p} P R_{3}$ & 23 & - & $\cdot$ & . & o \\
\hline WBI I & Tiny & - & + & \pm & o \\
\hline WBI & 0 & - & + & - & 0 \\
\hline$A 2 I$ & 0 & - & + & - & 0 \\
\hline WBI 38 & 20 & + & . & . & $I \cdot I$ \\
\hline
\end{tabular}

* ${ }_{5} \mathrm{MT}=5$-methyl-DL-tryptophan.

† ICR = ICR I9IA [3-chloro-7-methoxy-9-(3-[chloroethyl]amino propylamino)-acridine dihydrochloride], generously provided by $\operatorname{Dr}$ H. J. Creech. NTG $=N$-methyl- $N^{1}$-nitro- $N$-nitrosoguanidine. Reversion responses were determined in plate-tests as described by Brammar et al. (1967).

$\$$ The ratio of A-protein activity, measured in the presence of excess B protein, to B-protein activity, measured in the presence of excess A protein, in the conversion of indole to tryptophan.

and were not merely spontaneous tryptophan auxotrophs selected by penicillin enrichment, their map locations were investigated by PI transduction. Mutants of both classes showed very close linkage to $\operatorname{trp} A 23$, a missense mutant affecting the same codon as $A 46^{a s p}$ (Helinski \& Yanofsky, 1962; Berger \& Yanofsky, 1967). WBI I, the 'leaky' mutant, showed $0.06 \%$ recombination with $A 23$, suggesting a separation of three to four codons (Yanofsky, Drapeau, Guest \& Carlton, 1967), while the non-leaky mutant wBI showed no detectable recombination with $A 23$ (Table 2). A cross between the phenotypically different auxotrophs yielded $t r p^{+}$recombinants at a rate of $0.17 \%$. Allowing for the fact that this figure includes both wild and pseudowild recombinants, such a recombination frequency suggests a separation between the two mutants of about six codons. 
Table 2. Recombination of mutants derived from $A_{4} 6^{a s p} P R_{3} F R 7$ with $A 23$.

\begin{tabular}{llccc}
$\begin{array}{c}\text { Donor } \\
\text { (his }^{+} \text {cys }\end{array}$ & \multicolumn{1}{c}{ Recipient } & $\begin{array}{c}\mathrm{His}^{+} \text {or Cys } \\
\text { transductants }\end{array}$ & $\begin{array}{c}\text { Trp Cys }^{+} \\
\text {transductants }\end{array}$ & $\begin{array}{c}\text { Recombination } \\
(\%)\end{array}$ \\
WBI & hiscystrpA23 & $6300^{*}$ & 0 & $<0.016^{*}$ \\
WBI I & hiscystrpA23 & $13950^{*}$ & 9 & $0.065^{*}$ \\
WBII & cysWBI & $41500^{\dagger}$ & 35 & $0.177^{\dagger}$ \\
$A 46^{a s p} P R_{3}$ & cysWBI & $26450 \dagger$ & 16 & $0.12 \dagger$ \\
$A 46^{a s p} P R_{3}$ & cysWBI I & $12150 \dagger$ & 0 & $<0.017 \dagger$
\end{tabular}

* In crosses with hiscys $A 23$ as recipient, his is used as the reference marked: Cys $^{+}$, Trp ${ }^{+}$transductants are selected to avoid a high background due to reversion of the trp marker.

$\dagger$ When a cystrp recipient is used, cys is used as the reference marker. $\operatorname{Trp}^{+} \mathrm{Cys}^{+}$transductants were selected on plates containing $0 . \mathrm{I} \mu \mathrm{g} / \mathrm{ml}$ 5-methyl-DL-tryptophan to prevent the growth of leaky mutants WBII and $A 46^{a s p} P R_{3}$.

The genetic data are thus in excellent agreement with the expected behaviour of mutants derived by recombination of $A_{4} 6^{a s p} P R_{3} F R_{7}$ with wild-type. They would also suggest that the non-leaky mutant WBI contains both the $A 46^{a s p}$ missense mutation and a frameshift since it fails to recombine with $A 23$. The leaky mutant WBII is probably the base-addition frameshift mutation, since it fails to recombine with $A 46^{a s p} P R_{3}$, but does recombine with $A 23$ (Table 2). The ancestral strain $A 46^{a s b} P R_{3}$, which contains both the $A 46^{a s p}$ mutation and the base addition, is distinguishable from the leaky isolate WBI I by its slightly better growth on minimal agar (Table $\mathrm{I}$ ).

If the two classes of mutant recovered from $A 46^{a s p} P R_{3} F R 7$ are complementary frameshifts, then one or other must be of opposite phase to any other frameshift mutant. Thus it should be possible to produce pseudowild recombinants with a third closely linked frameshift mutant, provided the amino acid sequence generated by the altered reading frame between the two mutations is functionally acceptable. Mutant $\operatorname{trp} A 2 r$ contains a frameshift mutation of undefined phase located closely distal to the region defined by the two frameshift mutations in $\operatorname{trp} A 46^{a s p} P R_{3} F R_{7}$ (see Fig. 2) (Berger et al. I968). WBI I and WBI were therefore crossed with $\operatorname{trp} A 2 I$, and $\operatorname{tr} p^{+}$recombinants were selected. On subsequent purification and characterization, the WBII/A2I recombinants proved to be of two easily distinguished phenotypes; a fast-growing wild-type strain and a slower-growing pseudowild-type (WBI38). In contrast, WBI/A2I recombinants were all phenotypically indistinguishable from wild-type. The pseudowild recombinants produced a $\mathrm{CRM}^{+} \mathrm{A}$ protein with normal activity in the indole $\rightarrow$ tryptophan reaction (Table $\mathrm{I}$ ), and were presumed to contain frameshifts of opposite phase, derived from WBI I and $\operatorname{trpA2I}$. If this were the case, the codon sequence of the pseudowild recombinant would contain an in-phase tryptophan codon (UGG) generated from the third nucleotide of the phe $_{211}$ codon (UUU) and the first two nucleotides of the gly $_{212}$ codon $\left(\mathrm{GG}_{\mathrm{C}}^{\mathrm{U}}\right.$ ) (see Fig. 2). Thus, the partially active A protein from the pseudowild recombinant WBI 38 should contain a single tryptophan residue.

To test this prediction, the tryptophan synthetase A proteins from the WBI 38 recombinant and the wild-type parent strain were extensively purified as described in Methods and their tryptophan contents were assayed in two different ways. The first method employed the formula of Goodwin \& Morton (1946) to calculate the tryptophan and tyrosine contents directly from the u.v. absorption spectra in 0.1 M-sodium hydroxide. This method (Table 3 ) gave close to I mole of tryptophan/mole of the mutant A protein, while giving a suitably low value for the tryptophan content of the wild-type protein. The tyrosine content of the wild-type protein determined this way agreed well with the known value of 7 residues/mole (Yanofsky et al. 1967; Guest, Drapeau, Carlton \& Yanofsky, 1967). 


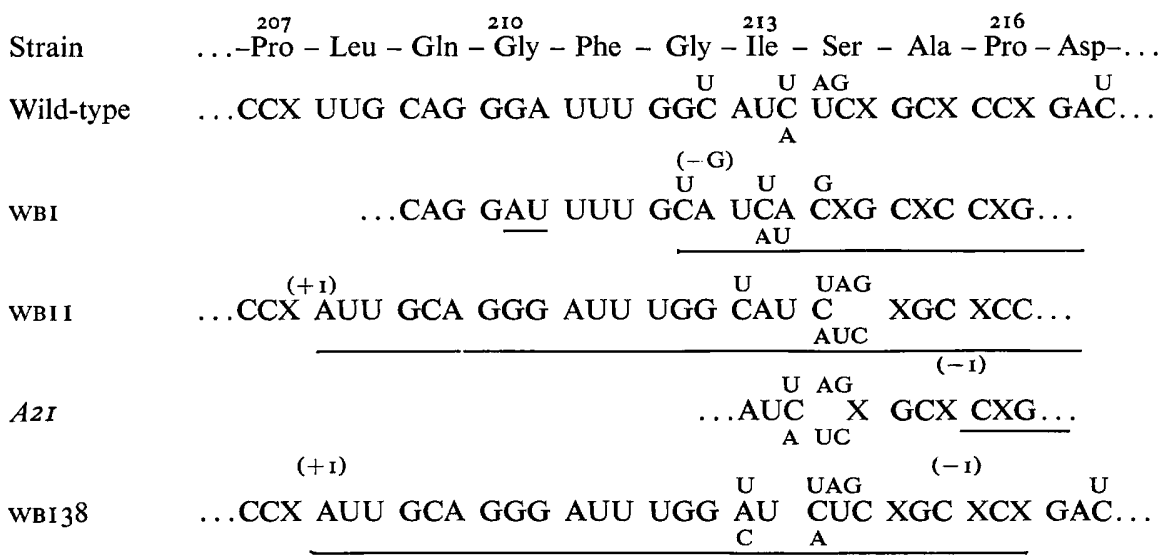

Fig. 2. The probable mRNA codon sequences for the $\operatorname{trp} A$ frameshift mutants and the WBI38 recombinant. Codons or nucleotides which differ from the wild-type are underlined. The information for $A 2 I$ is taken from Berger et al. (1968). Figures in parentheses represent mutational events.

Table 3. Spectrophotometric determination of tryptophan and tyrosine contents of wild-type and mutant $A$ proteins

Spectra were determined on $\mathbf{I} \cdot 0 \mathrm{mg}$ samples of each A protein in $\mathrm{I} \cdot 5 \mathrm{ml} 0 \cdot \mathrm{I} \mathrm{M}$-sodium hydroxide. Values were calculated using the formula of Goodwin \& Morton (1946), using an intersection wavelength of $294.4 \mathrm{~nm}$, and were corrected for background absorption.

$\begin{array}{lccc}\begin{array}{c}\text { Source of } \\ \text { A protein }\end{array} & \begin{array}{c}\text { Second } \\ \text { wavelength } \\ (\mathrm{nm})\end{array} & \overbrace{\text { Tryptophan }} & \text { Moles/mole of protein } \\ \text { Wild-type } & 270 & 0.05 & 7 \cdot 4 \\ & 280 & 0.30 & 7 \cdot 1 \\ & 290 & 0.03 & 7 \cdot 4 \\ \text { WBI38 } & 270 & 0.80 & 8 \cdot 0 \\ & 280 & 0.90 & 7 \cdot 9 \\ & 290 & 0.66 & 8 \cdot 2\end{array}$

The tryptophan content of the mutant enzyme was also determined by following the oxidative cleavage of carboxyl-tryptophanyl peptide bonds by $N$-bromosuccinimide spectrophotometrically at $280 \mathrm{~nm}$ (Patchornik, Lawson, Gross \& Witkop, I960). This method gave a value of 0.86 residues/mole for the mutant A protein, while showing no detectable tryptophan in the wild-type enzyme. The method was checked using lysozyme, bovine serine albumin and pancreatic ribonuclease, and in each case values obtained agreed very well with those from the literature (Table 4). Thus these determinations of the tryptophan content of the mutant A protein confirm the prediction that the protein contains a single residue of tryptophan.

A gene expression in the mutant trpAI38. The recombinant strain WBI38 is itself leaky for tryptophan biosynthesis. Thus, in order to study the expression of the mutant $A$ gene during tryptophan starvation it was necessary to introduce into the strain a complete genetic block on tryptophan synthesis. This was achieved by constructing a double mutant containing $\operatorname{trpET} 3$, a non-leaky missense mutant in the operator proximal $E$ gene, together with the WBI 38 mutation. The expression of the $A$ gene of this double mutant was compared with that of a $\operatorname{trp} E \operatorname{trp} A^{+}$transductant isolated from the same genetic cross.

The specific activities of tryptophan synthetase A and B proteins were followed over $40 \mathrm{~h}$ 


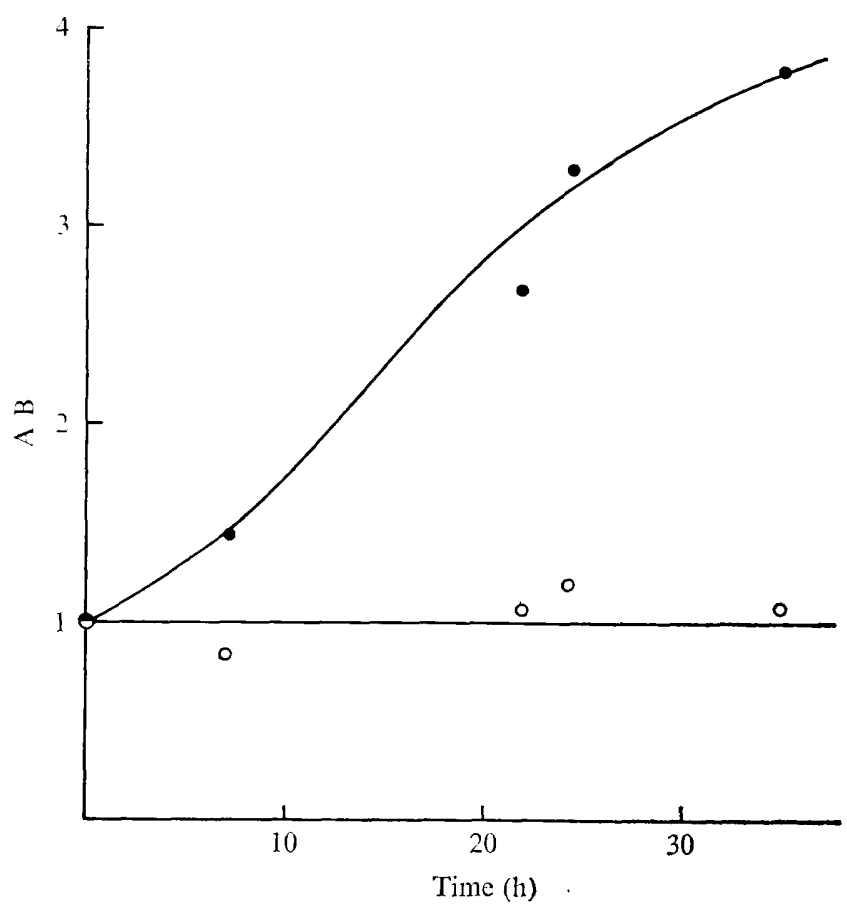

Fig. 3. The effect of tryptophan starvation on the synthesis of tryptophane synthetase A protein in $\operatorname{trp} A^{+}$and $\mathrm{WBI}_{3} 8$ strains. Both strains carried the $\operatorname{trp} p^{-}$missense mutant, $\operatorname{tr} p \mathrm{ET}_{3}$. Cultures were grown in minimal medium containing $0.05 \%(\mathrm{w} / \mathrm{v})$ acid-hydrolysed casein, $0.3 \%(\mathrm{w} / \mathrm{v})$ glucose and a growth-limiting concentration of L-tryptophan $(4 \mu \mathrm{g} / \mathrm{ml})$. Samples were harvested when growth stopped due to depletion of tryptophan (time 0 ), and at intervals for a further $36 \mathrm{~h}$. The data are plotted as the ratio of $A$ protein activity to $B$ protein activity to emphasise the differential synthesis of A protein. $\mathrm{O}-\mathrm{O}, \operatorname{trp} E T_{3}, \mathrm{WBI}_{3} 8 ;-\operatorname{trp} E T_{3}, A^{+}$.

\section{Table 4. Tryptophan contents determined by titration with $\mathrm{N}$-bromosuccinimide}

Samples $(2 \mathrm{mg}$ ) of each protein were dissolved in $\mathrm{r} \cdot 3 \mathrm{ml} 8 \mathrm{M}$-urea, adjusted to $\mathrm{pH} 4 \cdot 0$ with glacial acetic acid. Samples were titrated by addition of Io $\mu \mathrm{l}$ samples of Io mM- $N$-bromosuccinimide, and the decrease in absorption at $280 \mathrm{~nm}$ was followed. The calculations of the tryptophan contents were based on the following molecular weights: Lysozyme, $15000(a)$; bovine serum albumin, $65000(b)$; pancreatic ribonuclease, $14800(c)$; tryptophan synthetase A protein, $29500(d)$.

Tryptophan/mole of protein

\section{Protein}

Lysozyme

Bovine serum albumin

Pancreatic ribonuclease

A protein: wild-type

A protein: WBI 38

* Canfield \& Liu (1965).

‡ Hirs, Stein \& Moore (1960).

$\begin{array}{cc}\text { Determined } & \text { Reported } \\ 5 \cdot 3 & 6 * \\ 1 \cdot 5 & 2 \dagger \\ 0 & \circ \ddagger \\ 0 & \circ \S \\ 0.86 & .\end{array}$

$\dagger$ Peters \& Hawn (1967).

$\S$ Henning et al. (1962).

in the absence of tryptophan. The data, expressed as the ratio of $\mathrm{A}$ protein to $\mathrm{B}$ protein, are shown in Fig. 3. It is evident that the preferential synthesis of $\mathbf{A}$ protein observed with the $\operatorname{trp} A^{+}$strain, and with all other $A$ gene mutants examined, is eliminated in the strain which has a tryptophan residue in its A protein. 


\section{DISCUSSION}

The frameshift event which gave rise to $A 46^{a s p} P R_{3}$ created a tryptophan codon in the wild-type reading frame. The tryptophan synthetase A protein from $A 46^{a s p} P R_{3}$, although feebly active in vivo, could not be detected or analysed in vitro (Berger et al. 1968). Unfortunately, the mutational event which gave rise to the pseudowild revertant $A_{4} 6^{a s p} P R_{3} F R_{7}$ eliminated the $\operatorname{tr} p$ codon and created a cys codon in restoring the wild-type reading frame. By separating and recovering the component frameshift mutants from $A_{4} 6^{a s p} P R_{3} F R_{7}$, and then recombining one of them with another, more distal frameshift mutant $(A 2 I)$, it has been possible to create a double mutant which contains a trp codon in its $A$ gene.

The nature of the u.v.-induced mutational event in $\operatorname{trp} A 2 \mathrm{2I}$ had not previously been precisely defined: it could have been a deletion of either one or two nucleotides (Berger, Brammar \& Yanofsky, I969). Because $A 2 I$ is complementary in phase to the single nucleotide addition in $A_{4} 6^{a s p} P R_{3}$, the mutational event in $A 2 I$ must be a single nucleotide deletion.

In principle, it should be possible to recombine $A 46^{a s b} P R_{3}$ itself with $A 2 I$ to generate a multiple mutant and restore the wild-type reading frame. In practice, however, this would be very difficult to achieve, because $A 46^{a s p} P R_{3}$ itself grows relatively well on minimal medium. It is interesting that $A_{46}{ }^{a s p} P R_{3}$, which contains a frameshift mutation and two base-change mutations, grows very much better than WBII, which has only the frameshift event. This must be because the $A 46^{a s p} P R 3$ protein retains the wild-type phe residue at position 2 I I, whereas in the WBI I protein it must be replaced by an ile residue.

One of the two frameshift mutants isolated, WBI I, shows a significant reversion response with the alkylating mutagen NTG (see Table I). NTG has been previously observed to stimulate the reversion of some frameshift mutations (Yourno \& Heath, 1969), and it has been postulated that it does so by causing deletions of single base-pairs (Oeschger \& Hartman, 1970). The NTG-stimulated reversion of WBI I is not necessarily due to frameshift mutagenesis, however, since WBI I could give rise to partial revertants like $A 46^{a s p} P R_{3}$ by base-change mutations.

The purified tryptophan synthetase A protein from the recombinant strain WBI 38 was shown to contain I residue of tryptophan/mole of protein, both from its spectrum and by titration with $N$-bromosuccinimide. Control experiments with the wild-type enzyme and with three other proteins demonstrate the validity of the methods. These determinations could be criticized on the grounds that the protein preparations were not pure. The preparation of mutant A protein used for these determinations had a specific activity of $4000 \mathrm{u} . / \mathrm{mg}$, suggesting a purity of about $80 \%$. Care was taken to use a wild-type fraction with a similar specific activity. Since the two enzymes were purified by the same method it is probable that the two preparations contained the same impurities, and that the determined difference in tryptophan content is a real one. This conclusion is supported by inspection of peptide maps of tryptic digests of the two A proteins. The relevant wild-type peptide, TP 3, (Guest, Carlton \& Yanofsky, 1967) is missing from the peptide map of the mutant protein, but a new peptide is evident which shows the u.v. fluorescence characteristic of tryptophancontaining peptides (unpublished results).

The preferential synthesis of tryptophan synthetase A protein during tryptophan starvation is eliminated in the strain which contains a tryptophan codon in its $\operatorname{trp} A$ gene. This result directly confirms the suggestion that the preferential synthesis of A protein is due to the latter's lack of tryptophan. Since Morse, Mosteller \& Yanofsky (I969) have shown that tryptophan messenger RNA synthesis is normal during acute tryptophan starvation, the synthesis of A protein under these conditions must be due to independent translation of the 
$A$ gene region of messenger RNA. During tryptophan starvation ribosomes prior to a tryptophan codon would be arrested at the preceding codon (Capecchi, 1967; Bretscher, I968a). Thus the ribosomes which translate the $A$ gene messenger RNA must do so by internal attachment to the messenger RNA, at or near the beginning of the $A$ gene region. The conclusion that ribosomes can attach to internal positions in a messenger RNA molecule has already been obtained by several different methods (e.g. Lodish, I968; Spahr \& Gesteland, 1968; Bretscher, 1968b; Morse et al. 1969; Webster \& Zinder, 1969). It is not yet clear whether there is a specially coded ribosome-attachment site at the beginning of each gene, or whether a single initiation codon (AUG) will suffice.

It might be expected that acute starvation for a particular amino acid, in blocking ribosome movement, would act like a nonsense mutation and produce strong polarity. Morse \& Guertin (197I) have recently shown, however, that amino acid deprivation very effectively relieves polarity in Escherichia coli by a mechanism which involves stabilization of the unprotected messenger RNA.

The absolute rate of A-protein synthesis during prolonged tryptophan starvation is of interest. In these experiments the specific activity of wild-type A protein increased from $25 \mathrm{u} / \mathrm{mg}$ protein at $6 \mathrm{~h}$ to $73 \mathrm{u} / \mathrm{mg}$ after $24 \mathrm{~h}$ of starvation. This represents an increase of $48 \mathrm{u} / \mathrm{mg}$ in $\mathrm{I} 8 \mathrm{~h}$ (or $2 \cdot 7 \mathrm{u} / \mathrm{mg} / \mathrm{h}$ ), which corresponds to the synthesis of about $\mathrm{I} 350$ molecules of tryptophan synthetase/organism/h. On derepression with indole propionic acid, a logphase culture of the w3I Io strain synthesizes about 12000 molecules/organism/h (Morse, Baker \& Yanofsky, I968). Thus, under conditions in which the synthesis of other proteins has stopped due to lack of tryptophan, tryptophan synthetase A protein is synthesized at about $10 \%$ of its maximum rate.

I am indebted to Dr R. P. Ambler for helpful advice, to Drs C. Yanofsky and H. Berger for bacterial strains, and to Susanna Winton for valuable technical assistance.

\section{REFERENCES}

Allen, M. K. \& Yanofsky, C. (1963). A biochemical and genetic study of reversion with the $A$ gene A protein system of $E$. coli tryptophan synthetase. Genetics 48, 1065-1083.

Berger, H., Brammar, W. J. \& Yanofsky, C. (1968). Analysis of amino acid replacements resulting from frameshift and missense mutations in the tryptophan synthetase $A$ gene of Escherichia coli. Journal of Molecular Biology 34, 219-238.

Berger, H., Brammar, W. J. \& Yanofsky, C. (1969). Spontaneous and ICR-191-A-induced frameshift mutations in the $A$ gene of Escherichia coli tryptophan synthetase. Journal of Bacteriology 96, 1672-1679.

Berger, H. \& YANOFSKY, C. (1967). Suppressor selection for amino acid replacements expected on the basis of the genetic code. Science, New York r56, 394-397.

Brammar, W. J., Berger, H. \& YANOFSky, C. (1967). Altered amino acid sequences produced by reversion of frameshift mutants of the tryptophan synthetase $A$ gene of Escherichia coli. Proceedings of the National Academy of Sciences of the United States of America 58, I499-1 506.

BretsCher, M. S. (I968a). Polypepide chain termination: an active process. Journal of Molecular Biology 34, I3I-136.

BretSChER, M. S. (1968 b). Direct translation of a circular messenger DNA. Nature, London 220, I088-109I.

CANFiEld, R. E. \& LiU, A. K. (1965). The disulfide bonds of egg white lysozyme (muramidase). Journal of Biological Chemistry 240, 1997-2002.

CAPECCHI, M. R. (1967). Polypeptide chain termination in vitro: isolation of a release factor. Proceedings of the National Academy of Sciences of the United States of America 58, I I44-I I 5 I.

COHEN, G. N. \& JACOB, F. (1959). Sur la répression de la synthèse des enzymes intervenent dans la formation du tryptophane chez Escherichia coli. Comptes rendus des séances de l'Académie des sciences 248, 3490-3492. 
CRAWFORD, I. P. \& YANOFSKY, C. (1958). On the separation of the tryptophan synthetase of Escherichia coli into two protein components. Proceedings of the National Academy of Sciences 44, I 161-1 170.

Creighton, T. E. \& Yanofsky, C. (I969). Indole-3-glycerol phosphate synthetase of Escherichia coli, an enzyme of the tryptophan operon. Journal of Biological Chemistry 24r, 4625-4637.

Goodwin, T. W. \& MORTON, R. A. (1946). The spectrophotometric determination of tyrosine and tryptophan in proteins. Biochemical Journal 40, 628-632.

Guest, J. R., CARLton, B. C. \& YANOFSKy, C. (1967). The amino acid sequence of the A protein ( $\alpha$ subunit) of the tryptophan synthetase of Escherichia coli. I. Tryptic peptides. Journal of Biological Chemistry 242 , 5397-541 2.

Guest, J. R., Drapeau, G. R., Carlton, B. C. \& Yanofsky, C. (1967). The amino acid sequence of the A protein ( $\alpha$ subunit) of the tryptophan synthetase of Escherichia coli. V. Order of tryptic peptides and the complete amino acid sequence. Journal of Biological Chemistry 242, 5442-5446.

HeLINSKI, D. R. \& YANOFSKY, C. (1962). Correspondence between genetic data and the position of amino acid alteration in A protein. Proceedings of the National Academy of Sciences of the United States of America 48, 173-183.

Henning, U., Helinski, D. R., Chao, F. C. \& Yanofsky, C. (1962). The A protein of the tryptophan synthetase of Escherichia coli. Journal of Biological Chemistry 237, I523-1530.

HiRAGA, S. (1969). Operator mutants of the tryptophan operon in Escherichia coli. Journal of Molecular Biology 39, I 59-179.

Hirs, C. H. W., Stein, W. H. \& Moore, S. (I960). The sequence of the amino acid residues in performic acid-oxidized ribonuclease. Journal of Biological Chemistry 235, 633-647.

Imamoto, F., Morikawa, N. \& Sato, K. (1965). On the transcription of the tryptophan operon in E. coli. III. Multicistronic messenger RNA and polarity for transcription. Journal of Molecular Biology r3, 169-1 82.

IMAMOTO, F. \& YANOFSKY, C. (1967). Transcription of the tryptophan operon in polarity mutants of Escherichia coli. I. Characterization of the tryptophan messenger RNA of polar mutants. Journal of Molecular Biology 28, I-23.

Ito, J., Cox, E. C. \& YANOFsky, C. (1969). Anthranilate synthetase, an enzyme specified by the tryptophan operon of Escherichia coli: Purification and characterization of component I. Journal of Bacteriology 97, 725-733.

LenNox, E. S. (1955). Transduction of linked characters of the host of bacteriophage P I. Virology $\mathbf{r}$, 190-206.

LoDisH, H. (1968). Independent translation of the genes of bacteriophage f 2 RNA. Journal of Molecular Biology 32, 68I-685.

Lowry, D. H., Rosebrough, N. H., Farr, A. L. \& Randall, R. J. (I95I). Protein measurements with the Folin phenol reagent. Journal of Biological Chemistry 193, 265-275.

MORSE, D. E., BAKER, R. F. \& YANOFSKY, C. (I968). Translation of the tryptophan messenger RNA of Escherichia coli. Proceedings of the National Academy of Sciences of the United States of America 60, I428-1435.

MoRSE, D. E. \& GUERTIN, M. (I97I). Regulation of mRNA utilization and degradation by amino acid starvation. Nature New Biology, 232, 165-169.

Morse, D. E., MostelleR, R. D. \& YANOFSKY, C. (1969). Dynamics of synthesis, translation and degradation of trp operon messenger RNA in E. coli. Cold Spring Harbor Symposium for Quantitative Biology 34, 725-740.

Morse, D. E. \& YANOFSKY, C. (1969). Amber mutants of the trpR regulatory gene. Journal of Molecular Biology 44, I85-193.

Oeschger, N. S. \& HaRtman, P. E. (1970). ICR-induced frameshift mutants in the histidine operon of Salmonella. Journal of Bacteriology 101, 490-504.

Patchornik, A., Lawson, W. B., Gross, E. \& Witkop, B. (1960). The use of $N$-bromosuccinimide and $N$-bromoacetamide for the selective cleavage of C-tryptophyl peptide bonds in model peptides and glucagon. Journal of the American Chemical Society 82, 5923-5927.

Peters, T. JUn. \& HAWN, C. (1967). Isolation of two large peptide fragments from the amino and carboxyl terminal positions of bovine serum albumin. Journal of Biological Chemistry 242, I566-1573.

SMith, O. H. \& YANOFsKy, C. (1962). Enzymes involved in the biosynthesis of tryptophan. In Methods in Enzymology, vol. 5, pp. 794-806. Edited by S. P. Colowick and N. O. Kaplan. New York: Academic Press.

SOMERVILLE, R. L. \& YANOFSKY, C. (1964). On the translation of the $A$ gene region of tryptophan messenger RNA. Journal of Molecular Biology 8, 616-619. 
SPAHR, P. F. \& GeStelAND, R. F. (1968). Specific cleavage of bacteriophage R I 7 RNA by an endonuclease isolated from E. coli MRE 600. Proceedings of the National Academy of Sciences of the United States of America 59, 876-883.

SPIZIZEN, J. (1958). Transformation of biochemically deficient strains of Bacillus subtilis by deoxyribonucleate. Proceedings of the National Academy of Sciences of the United States of America 44, 1072-1078.

Swanstrom, M. \& Adams, M. H. (195I). Agar layered method for production of high titer phage stocks. Proceedings of the Society for Experimental Biology and Medicine 78, 373-375.

WEBSTER, R. E. \& ZINDER, N. D. (1969). Fate of the message-ribosome complex upon translation of termination signals. Journal of Molecular Biology 42, 425-439.

Whitfield, H. J., Jun., Martin, R. G. \& Ames, B. N. (I966). Classification of amino transferase (C-gene) mutants in the histidine operon. Journal of Molecular Biology 21, 335-355.

Yanofsky, C., Carlton, B. C., Guest, J. R., Helsinki D. R. \& Henning, U. (I964). On the colinearity of gene structure and protein structure. Proceedings of the National Academy of Sciences of the United States of America 51, 266-272.

Yanofsky, C., Drapeau, G. R., Guest, J. R. \& Carlton, B. C. (1967). The complete amino acid sequence of the tryptophan synthetase A protein ( $\alpha$ subunit) and its colinear relationship with the genetic map of the $\boldsymbol{A}$ gene. Proceedings of the National Academy of Sciences 57, 296-298.

YANOFSKY, C. \& LenNox, E. S. (I959). Transduction and recombination study of linkage relationships among the genes controlling tryptophan synthesis in Escherichia coli. Virology 8, 425-447.

Yourno, J. \& HEATH, S. (1969). Nature of the his D 3018 frameshift mutation in Salmonella typhimurium. Journal of Bacteriology roo, 460-468.

Zubay, G., Morse, D. E., Schrenk, W. J. \& Miller, J. H. M. (1972). Detection and isolation of the repressor protein for the tryptophan operon of Escherichia coli. Proceedings of the National Academy of Sciences of the United States of America 69, $1100-1103$. 